\title{
Sociální prevence a pedagogické aktivity proti diváckému násilí: přehled situace v Německu a v České republice
}

\section{Social prevention and pedagogic activities against spectator violence: Overview of situation in Germany and the Czech Republic}

\author{
Marek Suchánek, Miroslav Mareš
}

Fakulta sociálních studií Masarykovy univerzity v Brně

\begin{abstract}
Abstrakt
Tento př́spěvek se zabývá sociální prevencí a pedagogickým působením v oblasti boje proti diváckému násilí. Je v něm uskutečněno celkové zarámování této problematiky. Popsány jsou vysoce rozvinuté aktivity státní i nestátní sféry v Německu (streetwork, krizová intervence, individuální asistence apod.). Německé zkušenosti jsou konfrontovány se zkušenostmi z České republiky (např. sdruženi Pro Fotbal Fans). Je zmíněna role mezinárodnich organizaci (především Rady Evropy, UEFA a FIFA, včetně projektu ambasád pro fanoušky). $V$ závěru jsou obsažena doporučení pro pedagogickou oblast $v \check{C} R$.
\end{abstract}

\begin{abstract}
This paper deals with social prevention and pedagogic activities in the field of countering spectator violence (interconnected with sport). General framework of the whole issue is realized. Highly developed activities of the governmental as well as non-governmental sphere in Germany are described (streetwork, crisis intervention, individual assistance etc.). German experiences are confronted with experiences from the Czech Republic (association Pro Fotbal Fans, for example). Role of international organization is mentioned (mostly Council of Europe, UEFA and FIFA, including Fans Embassies project). Recommendations for educational sphere in the Czech Republic are included in conclusion.
\end{abstract}

Kličová slova: Divácké násilí, vzdělávání, preventivni projekty, fanoušci.

Key words: Spectator violence, education; prevention projects; fans

Tento článek byl zpracován v rámci projektu „Soudobé výzvy demokracii ve středovýchodní Evropě (GAP408/11/0709) “, financovaného z podpory Grantové agentury $\check{C} R$.

\section{ÚVOD}

V souvislosti s řadou incidentů souvisejících s diváckým násilím je možné klást si otázku, jakým způsobem proti tomuto fenoménu postupovat a kdo tak má činit. Kromě represivních prŕstupů se nabízejí i přístupy preventivní, mezi nimiž hraje důležitou roli i pedagogika a sociálně-preventivní práce, a to i za účasti nestátních aktérů. V tomto př́spěvku jsou představeny důležité koncepty a formy pedagogického působení proti diváckému násilí, které jsou zasazeny do kontextu širší prevence. Jako jistý modelový př́ípad je analyzována situace ve Spolkové republice Německo, následně je pozornost věnována situaci v České republice. Na tomto základě jsou formulována závěrečná doporučení pro pedagogickou praxi.

\section{OBECNÝ RÁMEC INTERAKCE DIVÁCKÉHO NÁSILÍ SE SOCIÁLNĚ-PREVENTIVNÍM A PEDAGOGICKÝM PŮSOBENÍM}

Divácké násilí je jedním fenoménů prolnutí sportu a násilí (v pojetí tohoto článku pod uvedený pojem tedy nespadá např. násilí na hudebně-subkulturních akcích). Sport a násilí se mohou dostat vzájemných vztahů v různých oblastech, jako je násilí mezi sportovci (hráči), násilí sportovců vůči rozhodčím a funkcionářům (výjimečně i proti divákům) a právě divácké násilí, které je tedy vybraným segmentem širší problematiky násilí 
se vztahem ke sportu. Je přitom třeba upozornit na provázanost jednotlivých segmentů (např. násilné či rasistické chování hráčů může stimulovat obdobné jednání i u diváků), čemuž odpovídá i potřebě široce zaměřené strategie působení proti násilí v souvislosti se sportem.

V souvislosti s bojem proti diváckému násilí jsou využívány v zásadě tři základní př́stupy:

1. Preventivně-sociální (včetně pedagogického působení), zaměřený na sociální a pedagogickou práci s diváky, kteří mohou páchat násilnou činnost;

2. Bezpečnostně-technický, zaměřený na odstrašující a odhalující využití technických prostředků (detektory, osobní prohlídky, kamerové systémy apod.);

3. Bezpečnostně-policejní (zaměřený na bezprostřední zásahy proti diváckému násilí a př́padné vyšetřování této činnosti ve správním anebo trestním řízení)(Bundesrat 2008: 2).

4. Právně-represivní (užití právních norem k potrestání pachatelů diváckého násilí).

I toto vymezení je třeba chápat analyticky, protože např. v oblasti prevence i represe se prolíná v ČR působení Antikonfliktních týmů Policie ČR), na právní represi navíc může navazovat i sociálně-preventivní a pedagogická práce s odsouzenými delikventy.

Obecně se pedagogické působení proti se odehrává především v rovině sociální pedagogiky, a zvláště pak v oblasti spolupráce s nevládními organizacemi. Tam mohou působit speciálně zaměření sociální pedagogové na tuto oblast, důraz je kladen i na mediální pedagogiku (v souvislosti s prezentací diváckého násilí) (Pilz 2006). Uvedené aspekty spolupráce nevládní a vládní sféry v oblasti sociální pedagogiky budou v následující části článku demonstrovány na konkrétních př́kladech ze SRN i ČR.

\section{SITUACE VE SPOLKOVÉ REPUBLICE NĚMECKO}

Německo patří ke státům, které mají dlouhodobě propracovanou koncepci práce se skupinami fotbalových př́znivců. Sociální prevence a pedagogické působení na potenciálně rizikové skupiny sportovních fanoušků tvoří důležitou část Národní koncepce sportu a bezpečnosti, která byla poprvé přijata v roce 1993. Projekty pro německé fotbalové fanoušky se však poprvé objevily již v osmdesátých letech XX. století. Na federální úrovni se organizací preventivní a pedagogické práce s fanoušky zabývá Koordinationsstelle Fan-Projekte bei der Deutschen Sportjugend (dále jen KOS, www.kos-fanprojekte.de). Počet dílčích projektů pro fotbalové fanoušky se od osmdesátých let XX. století značně rozrostl a dnes se preventivní a pedagogické práci se svými příznivci věnují takřka všechny profesionální fotbalové kluby. KOS každý rok vydává brožuru s přehledem uskutečněných aktivit jednotlivých existujících projektů při fotbalových klubech (Fanprojekte 2004, 2005). KOS navázal od roku 1993, kdy započal svou činnost, rovněž celou řadu aktivit se zahraničními organizacemi, které se věnují práci s fotbalovými fanoušky. Zástupci KOS jsou pravidelně zváni na zasedání pracovních výborů Rady Evropy a podílí se na prrípravě dokumentů vydávaných touto nadnárodní institucí. Německý model tak slouží jako vzor ostatním státům Evropské unie.

Hlavním specifikem německého přístupu je „pozitivní“ vnímání subkultury sportovních (zejména fotbalových) fanoušků. Vyškolení sociální pracovníci a pedagogové jsou součástí fanouškovských komunit a disponují tak vesměs výbornou znalostí konkrétních problémů a potřeb cílové skupiny. Důraz je kladen především na určitou seberegulaci uvnitř skupin fanoušků a podpora jednotlivců k osvojování si své vlastní odpovědnosti. Sociální pracovníci a pedagogové jsou tak v denním kontaktu s fanoušky, znají jejich zvyky, rituály a mají celkově velmi silné povědomí o celé scéně aktivních fotbalových př́znivců. Praktickou asistencí v každodenním životě fanoušků je dosaženo toho, že značná část (převážně mladých) fanoušků si uvědomí rizika možného delikventního jednání a vyhnou se tak př́ípadným potížím a postihům ze strany represivních orgánů. Mezi nejdůležitější aktivity v oblasti práce s fanoušky patří:

- „Opatření ke stabilizaci skupin fanoušků, fan-klubů a regionálních komunit fanoušků pomocí doprovázení a podílení se na skupinových procesech.

- $\quad$ Podpora a posilování individuálních iniciativ a odpovědnosti mezi fanoušky.

- $\quad$ Nekomerční volnočasové nabídky.

- Individuální poradenství.

- Asistování v obtížných a krizových situacích“ (Good hosting, fever problems, 2004).

Neméně důležitou součástí aktivit německých nevládních organizací je (spolu)práce s institucemi, nejčastěji s orgány státní správy a samosprávy, fotbalovými kluby a svazy, partnerskými nevládními organizacemi, nadnárodními organizacemi. 
Klíčovou rolí sociálních pracovníků, pedagogů či samotných vybraných vůdčích postav fanoušků je v této souvislosti poskytování informací a vyjednávání se zainteresovanými partnery. Cílem je předejít konfliktním situacím a otupit hrany při vzniklých sporech.

Mezi nejčastěji používané praktické metody sociálně preventivní práce s fotbalovými fanoušky patř́i:

- „Streetwork, tj. doprovázení skupin fotbalových fanoušků na místa jejich setkání a vytváření trvalých mezilidských vztahů.

- Krizová intervence, tj. poskytování podpory a vyjednávání v obtížných konfliktech a v naléhavých př́padech (projevy násilí, zranění, zatčení, atd.).

- $\quad$ Individuální asistence, tj. poskytování individuálního poradenství a podpory.

- Sociální práce se skupinou, tj. poskytování podpory skupinám fanoušků a jejich motivace k pozitivním aspektům fandovství (např. výroba choreografií).

- Volnočasové nabídky, tj. vytváření míst kde se mohou fanoušci setkávat, projektů vztahujících se ke sportu.

- $\quad$ Pedagogické, výchovné a vzdělávací aktivity.

- $\quad$ Kulturně pedagogická práce „(Fussball ohne Grenzen, 2001)“.

V konkrétní rovině jsou v Německu uskutečňovány např. turnaje různých skupin fanoušků (často dříve neprrátelsky orientovaných), fotbalová utkání s potenciálními mladými násilníky ve vězeních a výchovných ústavech, fotbalová utkání mezi fanoušky a policií, vzdělávací, přednáškové a diskusní akce za účasti různých aktérů majících vztah $\mathrm{k}$ diváckému násilí (zástupci akademické sféry, policie, fotbalových klubů, samosprávy, atd.).

Cíle jednotlivých preventivních projektů:

- $\quad$ Prevence násilí.

- $\quad$ Odbourávání extremistické orientace a delikventního jednání.

- $\quad$ Stabilizace skupin stejného věku a navracení mladistvých fotbalových přivrženců do jejich klubů.

Většina projektů pro fotbalové fanoušky při jednotlivých klubech sídlí ve svých vlastních prostorech. Nejčastěji jsou tyto tzv. klubovny umístěny v areálu fotbalových stadionů, někdy v blízkém okolí či v centrech měst (např. klubovna prŕznivců fotbalového celku HSV Hamburg zabírá trrípatrový dům nedaleko centra Hamburku, který byl věnován samosprávou). V klubovnách se mohou fanoušci setkávat, trávit tam svůj volný čas, připravovat společné aktivity vztahující se $\mathrm{k}$ podpoře oblíbeného fotbalového celku či se účastnit pedagogických a vzdělávacích kurzů.

Rada aktivit je vedena iniciativou samotných fotbalových fanoušků bez výraznějšího vedení vyškolených sociálních pracovníků či pedagogů. Některé projekty fanoušků jsou také značně autonomní. Jeden ze specifických projektů pro fanoušky funguje při hamburském fotbalovém klubu FC St. Pauli (Der Fanladen St. Pauli, od roku 1988). Fanoušci tohoto hamburského fotbalového klubu jsou radikálně levicově orientovaní, což se projevuje i v jejich oficiálních fanklubových aktivitách. Hlavním cílem Fanladen St. Pauli je boj proti rasismu a diskriminaci. Na fanklubových aktivitách se podílí řada př́slušníků minorit a specifických subkultur. V některých ohledech se Fanladen St. Pauli věnují spíše politickým otázkám než smysluplné preventivní a pedagogické práci se skupinou fotbalových př́znivců. Fanladen St. Pauli se tak spíše podobají nátlakovým skupinám italských ultras v devadesátých letech XX. století, pro které byla politická orientace a z ní vycházející aktivity určující. Vůdčí představitelé Fanladen St. Pauli jsou však velmi aktivní na poli spolupráce s nadnárodními organizacemi, zejména Stálým výborem Rady Evropy, což často přináší i úsměvné momenty, kdy aktivisté Fanladen St. Pauli na zasedání tohoto výboru rozdávají př́tomným samolepky s radikálně levicovou tématikou (nápisy Gegen Rechts či Fight Capitalism). Někteří členové Fanladen St. Pauli se rovněž dopouštějí výtržností při utkáních svého celku. Výsledky preventivní práce tohoto fanklubu, který má značnou podporu KOS tak mohou být problematizovány. Celkově však lze model, uplatňovaný ve Spolkové republice Německo, označit jako následováníhodný.

\section{SITUACE V ČESKÉ REPUBLICE}

V rámci České republiky neexistuje celostátně prosazovaná národní koncepce sportu a bezpečnosti obdobně, jako tomu je ve výše zmíněné Spolkové republice Německo. Problematika preventivní a pedagogické práce s cílovou skupinou sportovních fanoušků je roztř̌šš̌na mezi mnoho subjektů a není ucelena. Na centrální úrovni se oblasti sportu věnuje především Ministerstvo školství, mládeže a tělovýchovy (dále jen MŠMT). V rámci samotných preventivních a vzdělávacích aktivit pro fotbalové fanoušky však vystupuje aktivněji Ministerstvo 
vnitra a Policie ČR, což lze označit za určitý paradox. Dlouhodobě se preventivní práci se skupinami fotbalových fanoušků věnoval zejména odbor prevence kriminality Ministerstva vnitra. Díky práci tohoto odboru byla navázána úzká spolupráce s nadnárodními institucemi (především s Radou Evropy), analyticky uchopena problematika preventivních a vzdělávacích aktivit ve vztahu k fotbalovým fanouškům a podporovány projekty vztahující se ke sledovaným aktivitám.

Klíčová role preventivních a pedagogických aktivit v boji proti projevům diváckého násilí je reflektována i v analytickém a koncepčním materiálu odboru bezpečnostní politiky Ministerstva vnitra „Zpráva o situaci v oblasti diváckého násilí, dopadu koncepce v praxi a návrzích dalších opatření“ (dále jen Zpráva). Ve Zprávě je mj. především fotbalovým klubům doporučováno podporovat a spoluorganizovat oficiální fankluby, které by mohly do budoucna při správném pojetí, efektivní činnosti a poutavé sebeprezentaci, být pro mladé fanoušky důležitou alternativou k radikálním fanouškovským skupinám. Důležité na organizaci a pojetí takových projektů přitom je, aby byli fanoušci do těchto činností zapojováni aktivně, tedy nikoliv organizování akcí pro fanoušky, ale konání aktivit společně s fanoušky (Zpráva o situaci v oblasti diváckého násilí, 2010).

Ministerstvo vnitra a Ministerstvo školství, mládeže a tělovýchovy spolupracují v oblasti diváckého násilí především v rámci Koordinační komise k problematice diváckého násilí a nevhodného chování při sportovních utkáních, zvláště při fotbalových zápasech (dále jen Koordinační komise). Usnesením vlády č. 27 ze dne 11. ledna 1995 k návrhu na př́stup České republiky k Evropské úmluvě k diváckému násilí a nevhodnému chování při sportovních utkáních, zvláště při fotbalových zápasech bylo ministru vnitra uloženo, aby ustavil Koordinační komisi v souladu s článkem 2 Úmluvy. Na základě tohoto usnesení vlády byla uzavřena Dohoda o zř́zení Koordinační komise mezi Ministerstvem vnitra a Ministerstvem školství, mládeže a tělovýchovy. Dohoda mezi oběma subjekty byla uzavřena na dobu neurčitou. Koordinační komise byla pověřena koordinací postupů v boji proti diváckému násilí (Suchánek, 2004).

Koordinační komise zasedala ve formátu 8 stálých členů (6 z Ministerstva vnitra a 2 z Ministerstva školství, mládeže a tělovýchovy). K jednáním Koordinační komise byli pravidelně zváni rovněž zástupci Fotbalové asociace, Asociace profesionálních klubů ledního hokeje, Svazu měst a obcí, nevládních organizací, a další experti na danou problematiku.

\section{K činnosti Koordinační komise zejména patřilo:}

- Koordinace činnosti smluvních stran v oblasti dodržování Úmluvy v České republice.

- Spolupráce s občanskými sdruženími, zejména z oblasti tělovýchovy a sportu, a hromadnými sdělovacími prostředky za účelem eliminace diváckého násilí.

- Iniciace preventivní, výchovné, informační a pedagogické činnosti.

- Podpora výzkumných programů majících za cíl eliminovat případy diváckého násilí.

- Monitorování situace v oblasti diváckého násilí.

- Každoroční zpracovávání národních zpráv pro Stálý výbor Rady Evropy (Suchánek, 2004).

Koordinační komise byla po dlouhou dobu takřka jedinou fungující platformou pro setkávání se různých aktérů a diskutování problémů spjatých s diváckým násilím. Postupně však byla její činnost utlumována a jednotlivé problémy řešeny na ad hoc svolaných pracovních jednáních vždy pouze $\mathrm{k}$ určitému tématu. Aktuálně se Koordinační komise neschází.

V souvislosti s preventivní a pedagogickou činností v oblasti diváckého násilí podporují odpovědné instituce státní správy jednotlivé vybrané projekty, zejména prostřednictvím př́mé finanční podpory. Ucelená strategie a koncepce preventivní a pedagogické činnosti v oblasti diváckého násilí v České republice neexistuje a není ani v nejbližší době plánována.

Jednotlivé projekty preventivní a pedagogické práce s fanoušky jsou převážně uskutečňovány díky spolupráci státních institucí a dalších partnerů (nejčastěji sportovních svazů, sportovních klubů, orgánů samospráv a dalších). Klíčem k úspěchu je zejména dlouhodobá spolupráce a přesné rozdělení rolí jednotlivých aktérů. Níže je uveden ilustrativní přehled vybraných projektů preventivní a pedagogické práce s fotbalovými fanoušky. I přes ambici některých projektů se spíše jedná o lokálně omezené akce bez širšího dopadu na celostátní úroveň (s výjimkou níže zmíněného projektu ProFotbalFans či ambasád pro fotbalové fanoušky na velkých turnajích, které mají již celoevropský význam).

\section{Vybrané projekty preventivní práce s fanoušky}

Spuštění níže uvedených projektů předcházela rozsáhlá analytická zpráva ministerského odboru prevence 
kriminality, založená na zmapování aktuálně existující situace v oblasti preventivní práce s př́znivci všech tehdy působících prvoligových fotbalových klubů. Výsledkem zprávy bylo konstatování faktu, že soustavná preventivní a pedagogická práce $\mathrm{s}$ fanoušky neexistuje u žádného z oslovených klubů (Informace o možnostech projektů sociální práce s fanoušky - fan kluby, 2000). Výjimkou z pravidla byl v té době pouze fan klub fotbalového celku AC Sparta Praha, sdružující několik stovek členů spíše staršího věku, jehož činnost se omezovala na provozování obchodu se suvenýry a vydávání členských průkazů, opravňujících ke slevám ze vstupného na fotbalová utkání.

\section{Projekty fanklubů v Českých Budějovicích a v Liberci}

Jedním z prvních projektů, který byl odborem prevence kriminality Ministerstva vnitra podpořen, bylo založení „Junior fan-klubu“ v Českých Budějovicích v roce 2001. Projekt se věnoval práci s fanoušky místního fotbalového celku Dynamo České Budějovice mladšími patnácti let. Do této doby žádný podobný fanouškovský projekt v Českých Budějovicích neexistoval. Na založení „Junior fan-klubu“ se podílel místní prvoligový fotbalový klub a statutární město České Budějovice. V té době se podařilo zajistit pro členy malou klubovnu v areálu stadionu a dotaci 200 000,- Kč. Projekt byl plánován na obdobných zásadách, kterými se řídí fankluby v Německu. Byl koncipován jako nízkoprahové zařízení pro chlapce a děvčata ve věku od šesti do patnácti let. Provoz klubu zajišt’ovali bývalí fotbalisté. V plánu bylo vybavení klubovny vlastní televizí, počítačem a další technikou. Fanklub měl rovněž pravidelně vydávat svůj bulletin. V původně plánované podobě však „Junior fan-klub“ neměl dlouhého trvání (Informace o možnostech projektů sociální práce s fanoušky - fan kluby, 2000).

Finanční podpora ze strany odboru prevence kriminality Ministerstva vnitra byla poskytnuta rovněž projektu pro fanoušky při fotbalovém klubu Slovan Liberec. Také tento projekt byl inspirován německým př́kladem. Obdobně jako v případě Českých Budějovic je liberecký projekt zaměřen spíše na mladší fanoušky. Postupně byla $v$ rámci fotbalového stadionu U Nisy zř́zena klubovna pro fanoušky Slovanu na bázi nízkoprahového zařízení s cílem vytvoření odpovídajícího zázemí pro fanoušky, které by sloužilo pro realizaci pozitivně zaměřených aktivit (výroba choreografíí, organizace zájezdů, vytváření vlastních tiskovin a webových stránek, apod.). Cílem bylo předejít možné radikalizaci mladých fanoušků místního fotbalového celku a jejich př́klonu k extremistickým skupinám. Na rozdíl od českobudějovického př́padu je liberecký fanprojekt úspěšný a dlouhodobě fungující. Klíčovou roli sehrává především podpora ze strany samotného fotbalového klubu Slovan Liberec, u kterého je zakladatel fanprojektu př́mo zaměstnán.

V uplynulých cca deseti letech se i ostatní fotbalové kluby postupně zapojují do preventivní a pedagogické práce s fotbalovými fanoušky. V některých klubech vyvíjí aktivity samotné skupiny fotbalových přiznivců, snažících se prosadit své vlastní požadavky (např. na používání pyrotechniky při utkáních), což často naráží na nesouhlas jednotlivých fotbalových klubů. Ke vzájemné komunikaci mezi kluby a fanoušky (či dalšími partnery) kluby často pověřuí osoby z řad svých zaměstnancủ, které se těmto aktivitám věnují. Mít vyčleněného praco vníka pro kontakt $\mathrm{s}$ fanoušky je rovněž jedním z opakujících se požadavků Stálého výboru Rady Evropy. Postupně se zlepšující trend v této oblasti je patrný především u velkých fotbalových klubů s početnými skupinami př́íznivců (v poslední době např. AC Sparta Praha).

\section{Projekty „Fandíme slušněc}

Projekt „Fandíme slušně“ je zaměřený zejména na zvýšení právního povědomí mladých fanoušků a upozornění na rizika nežádoucího chování na stadionech. Na projektu se podílí fotbalový klub AC Sparta Praha ve spolupráci s Policií ČR. Partnerem projektu je Střední škola veřejnoprávní a vyšší odborná škola prevence kriminality a krizového řízení TRIVIS, která se zabývá vzděláváním v oblasti bezpečnostně právní. V uvedené škole jsou v rámci projektu vytvářeny podmínky k zařazení tématu do výuky s cílem př́pravy nových odborníků zaměřených na prevenci v oblasti diváckého násilí.

Náplní projektu je organizace besed ve vybraných školách, včetně diskuse s hráči a následnou autogramiádou. Součástí projektu jsou rovněž prezentace k tématu organizace fotbalového zápasu a činnosti Integrovaného záchranného systému při zajištování bezpečnosti na fotbalových zápasech. V rámci dohody s vybranými školami jsou těmto poskytovány motivační prvky na podporu slušného fandění (volné vstupenky na utkání, suvenýry, atd.). Cíle je rozš́říit tento projekt i na další fotbalové kluby v ČR.

Projekt „Fandíme slušně“ získal v roce 2011 třetí cenu v národním kole Evropské ceny prevence kriminality (Policie ČR - Ǩ̌P hl. m. Prahy, 2011). 
Projekty obdobného zaměření pod názvem „Fandíme sportu, fandíme slušně“ byly v uplynulých několika letech uskutečněny ve spolupráci několika partnerů (odbor prevence kriminality Ministerstva vnitra, krajská ředitelství Policie ČR, samospráva, vybrané základní a střední školy) rovněž ve městech Ostrava a Opava.

\section{Občanské sdružení ProFotbalFans a jeho aktivity}

Občanské sdružení ProFotbalFans (dále jen PFF) bylo založeno v záŕí 2004. Občanské sdružení bylo původně koncipováno jako odborná organizace působící v oblasti práce s fotbalovými fanoušky.

Náplní činnosti PFF měly být níže uvedené body:

- Pomoc při vytváŕení klima pro rozvoj projektů pro fotbalové fanoušky a práce $\mathrm{s}$ fanoušky a práce na profesionalizaci projektů i celé oblasti preventivní a pedagogické práce s fanoušky.

- Realizace vlastních projektů určených pro odbornou veřejnost, zejména vzdělávacích a výcvikových programů, výzkumných studií, apod.

- Organizace profesních setkávání, konferencí, seminářů, př́ipadně dalších odborných a vzdělávacích akcí.

- Spolupráce na dalších domácích i zahraničních projektech, které se týkají práce s fotbalovými fanoušky a podobných oblastí.

- Spolupráce s fotbalovými kluby, fotbalovým svazem a dalšími organizacemi a institucemi státní správy, samosprávy a nevládní sféry, a dále spolupráce s podobně zaměřenými zahraničními organizacemi (Návrh na registraci občanského sdružení ProFotbalFans, 2004).

PFF mělo být konzultantem klubům a pracovníkům při vytváření projektů pro fanoušky, získávání financí na ně a při realizaci jednotlivých projektů. Součástí aktivit PFF byl rovněž vzdělávací program pro kontaktní a sociální pracovníky pracující s cílovou skupinou fotbalových fanoušků. Vzdělávací program se uskutečnil za účasti německých lektorů, kteří seznámili přítomné účastníky kurzu s německým modelem preventivní a pedagogické práce s fanoušky. Vzdělávací program byl rozčleněn do několika bloků, sestávajících z teoretické výuky i praktické práce. Součástí vzdělávacího programu byla rovněž návštěva konkrétních německých projektů pro fanoušky. Do projektu byla v lektorské rovině zapojena německá organizace KOS. Hlavním cílem projektu PFF bylo vzdělání sociálních pracovníků a jejich př́prava na působení v oblasti sociální a klubové práce s fotbalovými fanoušky, především na úrovni klubů. Důraz byl kladen na vzdělávací aktivity, informační aktivity, výzkumnou část a podporu konkrétních projektů.

Projekt PFF měl sloužit jako základní platforma pro následný vznik preventivních a pedagogických projektů v jednotlivých fotbalových klubech v ČR. Projekt PFF byl zamýšlen jako obdoba KOS v Německu. Tento cíl se nepodařilo naplnit, nicméně projekt PFF sehrál významnou roli v řadě dílčích aktivit. Lidé zapojení do projektu se podíleli na činnosti tzv. ambasád pro fanoušky (při velkých fotbalových turnajích, jako bylo ME 2004 v Portugalsku, MS 2006 v Německu, ME 2008 v Rakousku a Švýcarsku, ME 2012 v Polsku), byl zpracován dotazníkový výzkum mezi návštěvníky fotbalových utkání a uskutečněna řada seminářů a konkrétních vzdělávacích aktivit. V současnosti není projekt PFF funkční, někteří jeho zakládající členové a účastníci vzdělávacích kurzů PFF však rozvíjejí své projekty a aktivity v oblasti preventivní a pedagogické práce $\mathrm{s}$ fotbalovými fanoušky.

\section{ROLE MEZINÁRODNÍCH ORGANIZACÍ}

\section{Rada Evropy}

Rada Evropy je první mezinárodní organizací zabývající se problematikou diváckého násilí. Agenda diváckého násilí je na jednáních Rady Evropy přítomna již od roku 1985, kdy byla přijata Evropská úmluva k diváckému násilí a nevhodnému chování při sportovních utkáních, zvláště při fotbalových zápasech (smluvní dokument Rady Evropy č. 120). Přijetí Evropské úmluvy bylo reakcí na narůstající př́pady diváckého násilí na národní i mezinárodní úrovni, které si vyžádaly několik desítek mrtvých.

Pro Českou republiku se stala Evropská úmluva závaznou od 1. června 1995. Vzhledem ke své dikci i vzhledem $\mathrm{k}$ tomu, že Parlament České republiky tuto úmluvu neratifikoval, neřadí se tato úmluva mezi mezinárodní smlouvy, které mají přednost před zákonem.

Úmluva je dále rozpracovávána doporučeními Stálého výboru Evropské úmluvy, který je podle článku 8 monitorovacím orgánem Evropské úmluvy. Doporučení Stálého výboru Rady Evropy se týkají bezpečnosti na stadionech, mezinárodní policejní spolupráce, prevence rasismu a xenofobie, preventivních a vzdělávacích 
opatření (především doporučení č. 1/2003 o úloze vzdělávacích a sociálních opatření při prevenci násilí ve sportu). Česká republika jakožto plnoprávný člen Rady Evropy a smluvní strana Evropské úmluvy má plnit veškeré své závazky plynoucí z těchto doporučení.

V rámci preventivní a pedagogické práce s fanoušky se doporučení týkají zejména níže uvedených oblastí (The prevention of violence in sport, 2005):

- $\quad$ Aktivit spojených $\mathrm{s}$ přivítáním hostujících diváků, v případě velkých šampionátů s budováním tzv. ambasád pro fanoušky.

- Dlouhodobé sociální a preventivní práci s fanoušky, zejména s problémovými skupinami fanoušků.

- $\quad$ Podpory klubů, aby zlepšily a rozšíríily svou spolupráci s fanoušky.

- Výzvám národním institucím, aby hrály rozhodující roli při rozvoji preventivních aktivit, zaměřených zejména na mládež.

Zasedání Stálého výboru Rady Evropy se konají pravidelně vždy dvakrát ročně ve Štrasburku či jiném zvoleném městě. Mimo tato zasedání je Stálým výborem pravidelně celoročně podporována řada preventivních a vzdělávacích aktivit (cílených kampaní, konferencí, seminářù, apod.) ve spolupráci s nevládními organizacemi, samosprávou či akademickou sférou. Zástupci z těchto společenských oblastí se rovněž aktivně účastí zasedání Stálého výboru Rady Evropy a spolupracují na př́pravě a realizaci materiálů tohoto výboru.

\section{Transnacionální fotbalové organizace UEFA a FIFA}

Diváckým násilím a podporou preventivních a vzdělávacích projektů pro fotbalové fanoušky se zabývají rovněž největší transnacionální fotbalové organizace - Svaz evropských fotbalových svazů (UEFA) a Mezinárodní federace fotbalových svazů (FIFA).

UEFA byla založena v roce 1954 a po prvních výraznějších problémech s projevy diváckého násilí se ve spolupráci s národními svazy snaží zlepšit situaci na fotbalových stadionech i mimo ně.

UEFA především podporuje fanoušky, kteří organizují aktivity proti projevům násilí a rasismu na fotbale a realizuje potřebnou osvětu $\mathrm{k}$ řešení vyvstalých problémů. Ze strany UEFA je nejvíce reflektovanou agendou boj proti všem formám rasismu a diskriminace. Jakékoliv projevy rasismu či etnické a národnostní nesnášenlivosti jsou delegáty UEFA pečlivě sledovány a kluby nebo národní fotbalové svazy jsou za chování svých fanoušků citelně sankcionovány. S ohledem na výše uvedené je v posledních letech patrná úzká spolupráce mezi vybranými mezinárodně působícími nevládními organizacemi zabývajícími se problematikou boje proti rasismu ve sportu a orgány UEFA. Zástupci nevládních organizací se podílí na přípravě materiálů UEFA, vystupují na konferencích (spolu)pořádaných UEFA a koncipují rovněž některé protirasistické kampaně (např. kampaně „Vykopněte rasismus z fotbalu“ či „Dejme rasismu červenou kartu“).

Obdobné aktivity ve vztahu k boji proti rasismu na fotbale vyvíjí také FIFA.

UEFA a FIFA se v roce 1999 společně podílely na založení Nadace Daniela Nivela, která se zabývá vědeckým výzkumem diváckého násilí, opatřeními $\mathrm{k}$ jeho předcházení a sbírkami na podporu jeho obětí. Nadace byla založena z podnětu Německého fotbalového svazu, který tím reagoval na brutální napadení francouzského četníka Daniela Nivela německými chuligány v průběhu Mistrovství světa ve fotbale v roce 1998 v Německu. Tuto aktivitu podpořily rovněž fotbalové svazy Anglie, Itálie a Nizozemí. Nadace uspořádala několik odborných seminářů a byla aktivní na sociálně-pedagogickém a vědeckém poli.

\section{Mezinárodně působící nevládní organizace fanoušků}

Rozvoj různých fanouškovských pozitivních aktivit se jeví jako účinný nástroj potírání násilí na stadionech (Balcar, 2000).

Především na evropské úrovni se organizují rovněž samotní fotbaloví fanoušci, kteří s násilím a rasismem nejen nesouhlasí, ale aktivně proti těmto jevům vystupují. Řada nevládních organizací fanoušků funguje na lokální a národní úrovni, mezinárodní spolupráce mezi jednotlivými organizacemi často probíhá neformálně a ad hoc. Vznikají však i stabilně a dlouhodobě působící evropské organizace a sítě fanoušků. Největší sítí sdružující několik desítek organizací je bezpochyby Football Against Racism in Europe (dále jen FARE). FARE vznikla v únoru 1999 a sdružuje několik desítek organizací fanoušků, které se věnují preventivní a pedagogické práci související zejména s bojem proti rasismu na fotbalových utkáních. FARE spolupracuje především s UEFA, FIFA, jednotlivými národními fotbalovými svazy, orgány Evropské unie a Stálým výborem Rady Evropy a aktivně se podílí na preventivních a pedagogických projektech těchto institucí. Zástupci FARE vystupují 
na jednáních partnerských institucí, podílí se na konferencích a vzdělávacích projektech. FARE např. vypracovala desetibodový protirasistický plán pro kluby, který následně přijala i UEFA.

Mezinárodně působící nevládní organizace fanoušků uskutečnily celou řadu akcí s významným dopadem. Jako jednu z nejdůležitějších aktivit lze označit fungování tzv. ambasád pro fanoušky při velkých fotbalových turnajích.

\section{Projekt Ambasád pro fanoušky}

Ambasády pro fanoušky působí jako poradní, informační a podpůrná služba pro fotbalové fanoušky, kteří za fotbalem cestují na velké turnaje do zahraničí. Počátky existence ambasád pro fanoušky se vztahují ke službám poskytovaným fanouškům anglické a německé fotbalové reprezentace na Mistrovství světa v kopané 1990 v Itálii (Fans Embassies at international tournaments, 2004). Koncept fan ambasád byl dále rozvíjen na všech následujících fotbalových turnajích. V současnosti již fan ambasády slouží fanouškům všech účastnických států mistrovství Evropy či světa ve fotbale.

V počátcích projektu fan ambasád se uplatňovaly dva přístupy. Anglický model začínal jako podpůrná a svépomocná iniciativa nevládní Asociace fotbalových fanoušků (Football Supporters Association, dále jen FSA). Činnost FSA byla nezávislá na anglické fotbalové asociaci i na vládních institucích. Naopak německé ambasády pro fanoušky byly vedeny zkušenými sociálními pracovníky, kteří se zároveň podíleli rovněž na klubových projektech pro fanoušky.

Postupným vývojem obou modelů (německého i anglického) došlo k jejich splynutí, byla vypracována metodologie činnosti fan ambasád a zejména od Mistrovství Evropy v kopané 2004 v Portugalsku lze vysledovat rostoucí specializaci a profesionalizaci služby fan ambasád. Ambasády pro fanoušky jsou tak neodmyslitelnou součástí každého většího turnaje v kopané a jsou plně podporovány hostitelskými státy, transnacionálními fotbalovými organizacemi a dalšími partnery.

Základem služeb fan ambasád je poskytování přesných, spolehlivých a aktuálních informací ze všech oblastí, které mohou fanoušky zajímat (údaje o hostujícím městě, způsobu dopravy na stadion, platných zákonných normách, možnostech zábavy, konzulárních službách, vstupenkách na utkání a jejich dosažitelnosti atd.). Pracovníci fan ambasád jsou v denním př́mém kontaktu s různými institucemi (městská samospráva, fotbalové asociace, pořadatelé, policejní sbory). Fan ambasády mohou být stacionární či mobilní, vždy jsou však umístěny na místech, kde se shromažd’ují fanoušci (nejčastěji centra měst, okolí fotbalových stadionů). Pracovníci fan ambasád mají k dispozici různé nástroje komunikace, samozřejmostí se stal tištěný průvodce pro fanoušky v národních jazycích toho kterého účastnického státu (Good hosting, fever problems, 2004).

Před vysláním vlastní fan ambasády se její vybraní pracovníci účastní několikadenních seminářủ, pořádaných nevládními organizacemi a dalšími partnery přímo na místě svého budoucího působení. Tyto stáže slouží k navázání důležitých kontaktů s hostitelskou zemí (Fans Embassies at international tournaments, 2004).

Česká ambasáda pro fanoušky se poprvé objevila na fotbalovém turnaji EURO 2000 v Belgii a Nizozemí. Odpovědnost za sestavení a vyslání týmu měl odbor prevence kriminality Ministerstva vnitra. Zástupci fan ambasád dalších účastnických států přitom byli delegováni fotbalovými asociacemi či nevládními organizacemi pro fanoušky. Podpora ze strany Ministerstva vnitra byla patrná i na všech následujících turnajích za účasti fotbalové reprezentace ČR. Od šampionátu EURO 2012 v Polsku je patrná větší zaangažovanost rovněž Fotbalové asociace $\breve{C}$.

Součástí činnosti fan ambasád je rovněž participace na pořádaných preventivních projektech pro fanoušky. Pravidelně se např́klad koná turnaj ve fotbale za účasti týmů, složených z fanoušků, jejichž národní reprezentace se probojovaly na šampionát. Členové fan ambasád se účastní také seminářů a jiných vzdělávacích aktivit, které mají za cíl přiblížit širší veřejnosti různé preventivní projekty pro fanoušky.

\section{ZÁVĚREČNÁ DOPORUČENÍ}

V souvislosti s výskytem fenoménu diváckého násilí mezi mládeží je v konkrétní lokalitě důležité zajistit sociálně-poradenskou a pedagogickou činnost orientovanou na mladé aktéry diváckého násilí. Je přitom třeba si uvědomit, že divácké násilí není jevem svázaným výhradně s mládeží, v chuligánských ganzích můžeme najít i dvougenerační členstvo (některé z gangů si dokonce zakládají mládežnické pobočky, v nichž starší chuligáni ve věku mezi třiceti a čtyřiceti lety „proškoluji “ mladší, včetně mladých lidí navštěvujících vyšší ročníky základních škol a střední školy).

V dané oblasti je třeba spolupráce prevence kriminality ve veřejné správě, policie, městské policie, 
sportovních svazů a oddílů a školy. Zodpovědné osoby (např. z komisí prevence kriminality či radní odpovědní za bezpečnost) mohou (i za pomoci policie a sportovních svazů) zjistit, zda existuje potenciál ke vzniku nevládní fanouškovské organizace zaměřené na eliminaci diváckého násilí, případně mohou kontaktovat již existující celostátní sítě a organizace s žádostí o pomoc (setkání, intervence, poradenství apod.). Následně je možné zahájit sociální práci s již angažovanými aktéry diváckého násilí (kde je však již často možnost pedagogického působení omezená, pokud se jedná o osoby, které se s diváckým násilím silně identifikovaly).

Ve školském prostředí v rizikovém prostředí je možné působit spíše na osoby, které se zatím pouze vzhlédly v násilných aktivitách, nejsou však do nich stabilně zapojeny. Je přitom třeba identifikovat skutečně rizikové fenomény ve školském prostředí a nevěnovat se sice ne zcela typickým, ale zároveň nerizikovým aktivitám (např. pokud žáci či studenti během přestávky hromadně zpívají běžný chorál lokálního klubu, chodí do školy s klubovými vlajkami a šálami či si barví obličej klubovými barvami, vzájemně se utvrzují v oddanosti klubu či národního týmu apod.). Rizikovými fenomény jsou především zanedbávání školní docházky ve prospěch účasti na činnosti násilného diváckého gangu, násilné střety kvůli klubové př́ílušnosti či př́slušnosti k národnímu týmu na půdě školy, včetně verbální a vizuální podpora uvedeného násilí a obecně prolnutí diváckého násilí $\mathrm{s}$ rasismem a extremismem

Prolnutí s rasismem a extremismem je třeba řešit pedagogickými postupy zaměřenými proti těmto fenoménům, které již byly odborně zpracovány (Mareš, Smolík 2010). V př́ípadě objevení se dalších uvedených rizikových fenoménů je třeba posilovat především aspekty slušného fandění, ne se snažit žáky či studenty odradit od sportovního fandění jako takového. Je možné zajistit na škole besedu vybraných žáků a studentů s hráči či zástupci nevládních organizací, př́ípadně je požádat, aby se podíleli na vytvoření pobočky takové organizace v lokalitě a zapojily do ní místní mládež. Důležitá může být i osobní angažovanost oblíbených učitelů v takových strukturách. Ve spolupráci se sportovním klubem a místní státní správou a samosprávou se školská zařízení mohou spolupodílet i na uskutečňování volnočasových aktivit pro rizikové skupiny (fotbalové turnaje znepřátelených skupin, besedy, společné výjezdy na reprezentační zápasy apod.). I když divácké násilí nelze potírat výhradně pedagogickými př́stupy, ty mohou k jeho eliminaci v konkrétních př́ípadech výrazně přispět.

\section{LITERATURA}

Balcar, M. (2000): Sociální práce s hooligans. Praha: Univerzita Karlova.

Bezpeči na sportovních utkáních. Manuál pro fotbalové kluby (2008). Praha: odbor bezpečnostní politiky MV, 2008.

Bundesrat (2008:): Gewalt anlässlich von Sportveranstaltungen Präventionsmassnahmen. Dostupné z http://www.baspo.admin.ch/internet/baspo/de/home/themen/foerderung/breitensport/fairness/gewaltbekaempfung.parsys.41955.downloadList.58314.DownloadFile.tmp/gewaltberichtinklkonkordatstextd.pdf

Bureš, R. (2005): Role Rady Evropy při prevenci diváckého násili na sportovních stadionech. In: Rada Evropy: Prevence diváckého násili při sportovnich utkáních. Role mistních a regionálních orgánů veřejné správy $v$ prevenci násili prí sportovních utkáních. Praha: MV ČR.

Council of Europe (2005): The prevention of violence in sport. Štrasburk: Council of Europe.

Council of Europe (2005): Youth work with fan clubs. Štrasburk: Council of Europe.

Evropská úmluva $k$ diváckému násili a nevhodnému chování při sportovních utkáních, zvláště při fotbalových zápasech (1996). Koordinační komise k problematice diváckého násilí a nevhodného chování při sportovních utkáních při MV C̆R. Praha: odbor prevence kriminality MV.

Fanprojekte 2005 (2005). Frankfurt nad Mohanem: Football Supporters International.

Fans Embassies at international tournaments (2004). Frankfurt nad Mohanem: KOS.

Fussball ohne Grenzen (2001). Frankfurt nad Mohanem: KOS.

Good hosting, fewer problems. A methodological guide on concepts and measures of socio-prevention in the framework of football supporters work (2004). Offenbach: KOS.

Informace o možnostech projektů sociální práce s fanoušky - fan kluby (2000). Praha: odbor prevence kriminality MV.

Mareš, M., Smolík, J., Suchánek, M. (2004): Fotbaloví chuligáni. Evropská dimenze subkultury. Brno: Centrum strategických studií.

Mareš, M. \& Smolík, J. (2010): Školní výuka a politický extremismus. Pedagogická orientace, roč. 20, č. 2, s. 40-54. ISSN: 1211-4669. 
Návrh na registraci občanského sdružení ProFotbalFans ze dne 20. 9. 2004.

Pilz, G. (2006): Fußballfankulturen und Gewalt - Wandlungen des Zuschauerverhaltens: Vom Kuttenfan und Hooligan zum postmodernen Ultra und Hooltra. Hannover: Leibniz Universität. Dostupné z http://www.sportwiss.uni-hannover.de/online-publikationen_sw.html

Policie ČR - Krajské ředitelství policie hl. m. Prahy (2011): Fandíme slušně. Dostupné z http://www.policie.cz /clanek/fandime-slusne-671540.aspx

Rozhodnutí Rady EU o bezpečnosti v souvislosti s fotbalovými zápasy s mezinárodním prvkem (2002/348/JHA) (2002). Praha: MV ČR.

Smolík, J. (2008): Fotbalové chuligánství. Historie, teorie a politizace fenoménu. Karlovy Vary: Zdeněk Plachý. Suchánek, M. (2004): Aktivity státních institucí ČR v problematice diváckého násilí. Éthum. Bulletin pro sociální prevenci, pomoc a intervenci, 43/2004.

Zpráva o situaci v oblasti diváckého násilí, dopadu koncepce v praxi a návrzích dalších opatření. Praha: odbor bezpečnostní politiky MV, 2010. 